\title{
Studies on Interacting Blends of Acrylated Epoxy Resin Based Poly(Ester-Amide)s and Vinyl Ester Resin
}

\author{
Pragnesh N. Dave ${ }^{1 *}$, Nikul N. Patel $^{2}$ \\ ${ }^{1}$ Department of Chemistry, KSKV Kachchha University, Gujarat, India; ${ }^{2}$ Institute of Technology, Nirma University, Ahmedabad, \\ India. \\ E-mail: pragneshdave@gmail.com
}

Received January $24^{\text {th }}, 2011$; revised March $23^{\text {rd }}$, accepted May $27^{\text {th }}, 2011$.

\begin{abstract}
Epoxy resin based Unsaturated poly(ester-amide) resins (UPEAs) can be prepared by many methods but here these were prepared by reported method [1]. These UPEAs were then treated with acrylotl chloride to afford acrylated UPEAs resin (i.e. AUPEAs). Interacting blends of equal proportional AUPEAs and vinyl ester epoxy (VE) resin were prepared. APEAs and AUPEAs were characterized by elemental analysis, molecular weight determined by vapour pressure osmometer and by IR spectral study and by thermogravimetry. The curing of interacting blends was monitored on differential scanning calorimeter (DSC). Based on DSC data in situ glass reinforced composites of the resultant blends have been prepared and characterized for mechanical, electrical and chemical properties. Unreinforced blends were characterized by thermogravimetry (TGA).
\end{abstract}

Keywords: Unsaturated Bisamic Acid, Epoxy Resin, Unsaturated Poly(Ester-Amide) Resin (Upeas), Acrylation, Vinyl Ester (VE) Resin, Differential Scanning Calorimetry, Thermogarvimetry, Glass Reinforced Composites

\section{Introduction}

Both the polyesters and polyamides discussed have particular individual properties and applications. Hence many researchers have synthesized co-poly (ester-amide)s from different raw materials in order to obtain the properties and applications of the individual ones into one segment. Some of the poly (ester-amide)s synthesized by different researchers. The three polymer candidates namely epoxy resin, unsaturated poly ester and polyamides are most widely versatile industrial materials and have broad spectrum of characteristics for wide applications ranging from aerospace to micro electronics. They are also important as laminating resins, moulding composites, fibers, films, surface coating resins, fiber cushion [3,4]. Particularly Polyamides material used in the form of fibers as especially thermoplastics of particular used in engineering applications. The glass fiber reinforced nylon plastics are now of substantial importance due to rigidity and creep resistance. Polyamides are also used in fiber application, automotive industries, valve covers, coatings $[5,6]$.

Merging of all three segments (i.e. epoxy, ester and amide) into saturated and unsaturated polymer chain has been recently reported from our Indian scientists [7-10]. Certain properties of resins may also be improved via interact of with the other unsaturated resin is another possibility. In order to improve certain properties of such reported USPEAs their blending with commercial vinyl ester epoxy resin is possible. While vinyl ester resin is versatile industrial resin today $[11,12]$ Hence the present paper comprises studies of interacting blending of reported unsaturated poly(ester-amide) resin with vinyl ester (VE) resin. The glass fiber reinforced composites of these blends have been fabricated and characterized by chemical, mechanical and electrical properties. The whole work is scanned in Scheme 1.

\section{Materials and Methods}

\subsection{Materials}

Commercially available epoxy resin, diglycidyl ether of bisphenol-A and vinyl ester epoxy resin was obtained from local market.

The specification of diglycidyl ether of bisphenol-A (DGEBA) are as follows: 


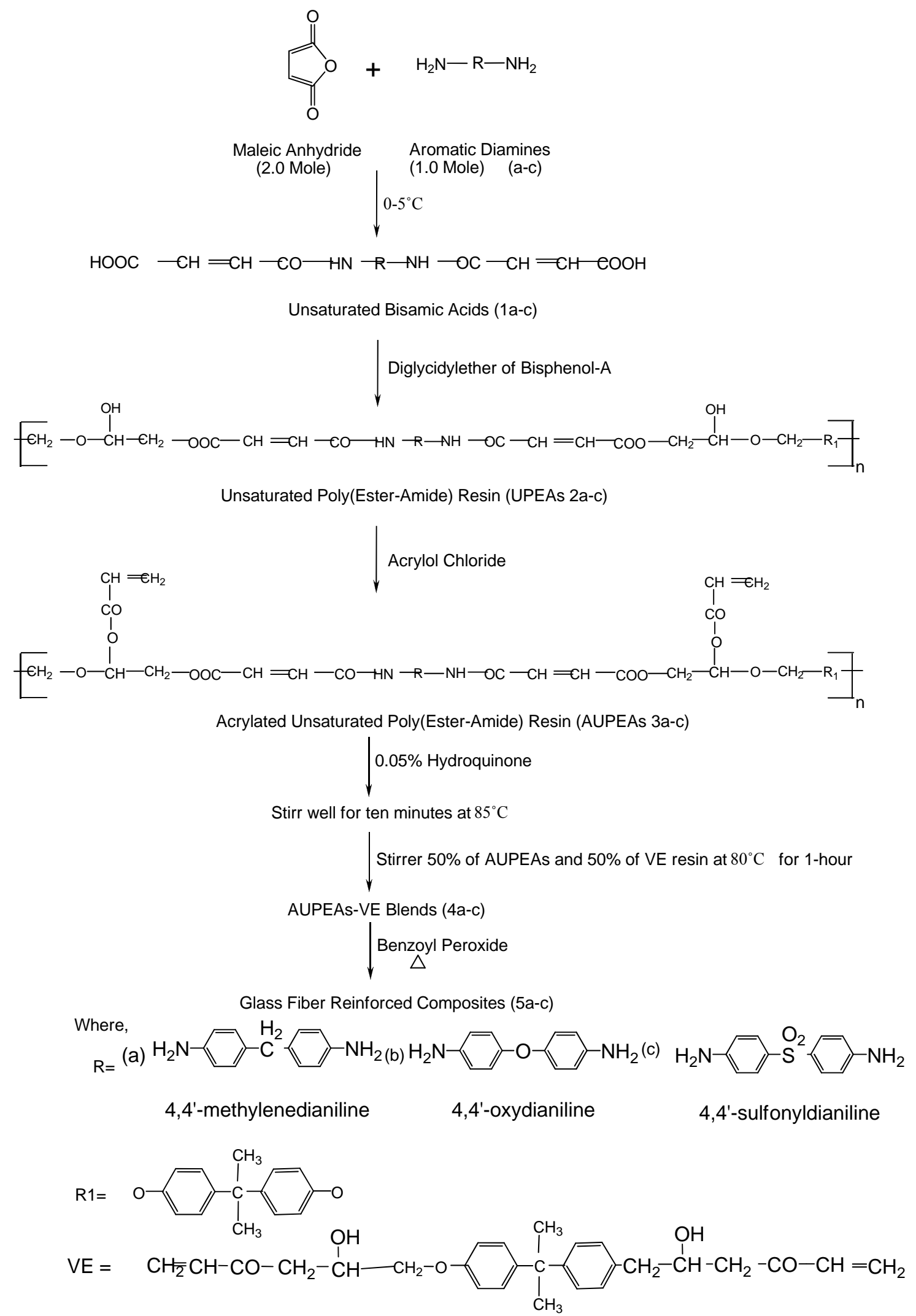

Scheme 1. Synthesis Steps. 
1) Epoxy equivalent weight, 190.

2) Viscosity $40-100$ poise at $25^{\circ} \mathrm{C}$.

3)Density at $25^{\circ} \mathrm{C}, 1.16-1.17 \mathrm{~g} / \mathrm{cm}$.

Vinyl ester epoxy.

The aromatic diamines used for the preparation of unsaturated poly(ester-amide) resin are,

1) 4,4'-methylenedianiline

2) 4,4'-oxydianiline

3) 4,4'-sulfonyldianiline

Plain weave fibers, in the form of E-glass woven fabric (poly (ester-amide) compatible) $0.25 \mathrm{~mm}$ thick (Unnati Chemicals, India) of a real weight $270 \mathrm{~g} \cdot \mathrm{m}^{-2}$ were used for composite fabrication. All other chemicals used were of pure grade.

\subsection{Synthesis of Unsaturated Bisamic Acids}

The unsaturated bisamic acid was prepared by a simple addition reaction of maleic anhydride and diamines. These were prepared by using method reported in the literature $[7,8]$. The general procedure for the synthesis of unsaturated bisamic acid is as follows.

To a well-stirred solution of maleic anhydride (2.0 mole) in dry acetone, the solution of diamine (1.0 mole) in dry acetone was gradually added at $0^{\circ} \mathrm{C}-5^{\circ} \mathrm{C}$ within 30 minutes. After complete addition of the diamine, the reaction mixture was further stirred for half an hour at room temperature. The resulting unsaturated bisamic acid was then filtered, washed with dry acetone and air-dried. Unsaturated bisamic acid was obtained in the form of free flowing powder. The reaction scheme for the synthesis of unsaturated bisamic acid is shown in Scheme 1.

\subsection{Synthesis of Unsaturated Poly(Ester-Amide) Resin and Acrylated Poly(Ester-Amide) Resin}

The unsaturated poly(ester-amide) resin (UPEAs) was prepared by following the same method reported in $[7,8]$ The general procedure is as follows:

Diglycidylether of Bisphenol-A (DGEBA) (1.0 mole) and unsaturated bisamic acid (1.0 mole) were charged in three necked flask equipped with a mechanical stirrer. The unsaturated bisamic acid was then treated with diglycidylether of Bisphenol-A according to method reported for reaction of epoxy resin and carboxylic group [13]. To this $8.0 \%$ of the total weight of above, triethylamine (TEA) was added as a base catalyst. The reaction mixture was slowly heated up to $85^{\circ} \mathrm{C}$ with continuous stirring till the acid value fell below $60 \mathrm{mg} \mathrm{KOH} / \mathrm{gm}$. The resultant resin was then discharged and called unsaturated poly(ester-amide) resin (UPEAs) and their details are furnished in Table 1. Further reaction of all these unsaturated poly(ester-amide) resin (UPEAs) was carried out with acryloyl chloride (i.e. acrylation) and the resultant products called acrylated poly(ester-amide)s (APEAs) and their details are furnished in Table 2.

\subsection{Synthesis of Acrylated Poly(Ester-Amide) Resin and Vinyl Ester Resin Blend}

When the acid value of acrylated poly(ester-amide)s fell below $55 \mathrm{mg} \mathrm{KOH} / \mathrm{gm}, 0.05 \%$ of hydroquinone was added as an inhibitor. The whole reaction stirred well for ten minutes maintaining the temperature at $85^{\circ} \mathrm{C}$. Then add $50 \%$ of APEAs and $50 \%$ of vinyl ester (VE) resin was added and stirred well at $80^{\circ} \mathrm{C}$ for one hour. The resultant APEAs-VE blends were obtained in the form of viscous syrup.

\section{Analysis and Thermal Study}

\subsection{Elemental Analysis}

The C, H, N content of unsaturated poly(ester-amide)s (UPEAs) and acrylated poly(ester-amide)s (APEAs) was estimated by means of Thermofinagan 1101 flash ele-

Table 1. Characterization of UPEAs (2a-c).

\begin{tabular}{|c|c|c|c|c|c|}
\hline \multirow[t]{2}{*}{ UPEAs } & \multicolumn{3}{|c|}{ Elemental analysis (Wt\%) Calc. / (Found) } & \multirow{2}{*}{$\begin{array}{l}\text { No. of }-\mathrm{OH} \text { group } \\
\text { per repeating unit }\end{array}$} & \multirow{2}{*}{$\begin{array}{l}\text { Number average molecular } \\
\text { weight }(\overline{\mathrm{Mn}}) \pm 60\end{array}$} \\
\hline & $\% \mathrm{C}$ & $\% \mathbf{H}$ & $\% N$ & & \\
\hline $2 \mathrm{a}$ & $65.62 / 64.23$ & $5.72 / 5.50$ & $6.43 / 5.83$ & 1.96 & 3902 \\
\hline $2 b$ & $64.06 / 63.83$ & $5.20 / 4.86$ & $3.64 / 3.15$ & 1.82 & 3828 \\
\hline $2 \mathrm{c}$ & $60.29 / 60.12$ & $4.90 / 4.63$ & $3.43 / 3.05$ & 1.81 & 4206 \\
\hline
\end{tabular}

Table 2. Characterization of AUPEAs (3a-c).

\begin{tabular}{|c|c|c|c|c|c|}
\hline \multirow{2}{*}{ AUPEAs } & \multicolumn{3}{|c|}{ Elemental analysis (Wt\%) Calc. / (Found) } & \multirow{2}{*}{$\begin{array}{l}\text { No. of double bonds per } \\
\text { repeating unit }\end{array}$} & \multirow{2}{*}{$\begin{array}{l}\text { Number average mo- } \\
\text { lecular weight }(\overline{\mathrm{Mn}}) \pm 60\end{array}$} \\
\hline & $\% \mathrm{C}$ & $\% \mathbf{H}$ & $\% \mathbf{N}$ & & \\
\hline $3 a$ & $65.75 / 65.37$ & $5.74 / 5.48$ & $3.19 / 2.63$ & 3.91 & 4133 \\
\hline $3 b$ & $64.38 / 63.87$ & $5.02 / 4.70$ & $3.19 / 2.91$ & 3.76 & 4135 \\
\hline $3 c$ & $63.22 / 62.88$ & $4.93 / 4.62$ & $3.13 / 2.61$ & 3.81 & 4428 \\
\hline
\end{tabular}


mental analyzer (Italy). The IR spectra were recorded in Kerr pellets on a Nicollet 760 D spectrometer. The number average weight of unsaturated poly(ester-amide)s (UPEAs) and acrylated poly(ester-amide)s (APEAs) was estimated by non-aqueous conductometric titration following by method reported in the literature [14]. Pyridine was used as a solvent and tetra-n-butyl ammonium hydroxide was used as a titrant.

\subsection{Thermal Study}

Curing of all APEAs-VE blends were carried out on a differential scanning calorimeter (DSC) by using benzoyl peroxide as a catalyst. A Du Pont 900 DSC was used for this study. The instrument was calibrated using standard indium metal with known heat of fusion $(\Delta \mathrm{H}=28.45 \mathrm{~J} / \mathrm{g})$. Curing was carried out from $30^{\circ} \mathrm{C}-300^{\circ} \mathrm{C}$ at $10^{\circ} \mathrm{C} \mathrm{min}^{-1}$ heating rate. The sample weight used for this investigation was in the range of $4-5 \mathrm{mg}$ along with an empty reference cell. The results are furnished in Table 3.

Unreinforced cured samples of APEAs-VE blends were subjected to thermogravimetric analysis (TGA) on $\mathrm{Du}$ Pont 950 thermo gravimetric analyzer in air at a heating rate of $10^{\circ} \mathrm{C} \mathrm{min}^{-1}$. The sample weight used for this investigation was in the range of $4-5 \mathrm{mg}$. The results are furnished in Table 4.

\section{Composite Fabrication}

The composites were prepared by using E-type of glass fiber. The glass fiber: APEAs-VE blend ratio is 60:40 (40\% APEAs-VE blends). Suspensions of APEAs-VE blends were prepared in tetrahydrofuran (THF). In the above polymer suspension, $1 \%$ of ethylene dimethylacrylate (as a cross linking agent) with $0.05 \%$ benzoyl peroxide (as an initiator) were added and mixed well. The mixture was applied with a brush to a $200 \mathrm{~mm} \times 200$ $\mathrm{mm}$ glass cloth and the solvent was allowed to evaporate. The ten dried prepregs prepared in this way were then stacked one on top of another and pressed between steel plates coated with a "Teflon" film release sheet and compressed under 70 psi pressure. The prepregs stacks were cured by heating it in an autoclave oven at around $140^{\circ} \mathrm{C}$ for about 6 hour. The composites so obtained were cooled to $45^{\circ} \mathrm{C}-50^{\circ} \mathrm{C}$ before the pressure was released.

\subsection{Composite Characterizations}

\subsubsection{Chemical Resistance Test}

The resistances against Chemicals of the composites were measured according to ASTM D 543. The results are furnished in Table 5.

\subsubsection{Mechanical and Electrical Testing}

1) The Flexural strength was measured according to ASTM D 790.

2) The Compressive strength was measured according to ASTM D 695.

3) The Impact strength was measured according to ASTM D 256.

4) The Rockwell hardness was measured according to ASTM D 785.

5) The Electrical strength was measured according to ASTM D 149.

6) The Tensile elongation was tested according to

Table 3. DSC Curing of UAPEAs-Vinyl ester epoxy resin Blends (4a-c).

\begin{tabular}{cccc}
\hline UAPEAs-VE resin Blends & \multicolumn{3}{c}{ Curing Temperature $\left(^{\circ} \mathbf{C}\right)$} \\
\cline { 2 - 4 } & $\mathbf{T i}$ & $\mathbf{T p}$ & $\mathbf{T f}$ \\
\hline $4 \mathrm{a}$ & 130 & 151 & 172 \\
$4 \mathrm{~b}$ & 116 & 147 & 174 \\
$4 \mathrm{c}$ & 126 & 138 & 186 \\
\hline
\end{tabular}

Table 4. TGA of Unreinforced Cured Samples of UAPEAs-Vinyl ester epoxy resin Blends (5a-c)-BPO system.

\begin{tabular}{cccccc}
\hline \multirow{2}{*}{$\begin{array}{c}\text { UAPEAs-VE resin } \\
\text { Blends }\end{array}$} & \multicolumn{5}{c}{ \% Weight loss at various temps. $\left({ }^{\circ} \mathbf{C}\right)$ from TGA } \\
\cline { 2 - 5 } & $\mathbf{1 5 0}^{\circ} \mathbf{C}$ & $\mathbf{3 0 0}^{\circ} \mathbf{C}$ & $\mathbf{4 5 0}^{\circ} \mathbf{C}$ & $\mathbf{6 0 0}^{\circ} \mathbf{C}$ & $\mathbf{7 5 0}^{\circ} \mathbf{C}$ \\
\hline $5 \mathrm{a}$ & 2.01 & 9.34 & 64.23 & 77.32 & 81.34 \\
$5 \mathrm{~b}$ & 1.87 & 9.21 & 68.56 & 76.63 & 79.34 \\
$5 \mathrm{c}$ & 1.71 & 8.03 & 65.25 & 75.87 & 80.06 \\
\hline
\end{tabular}

Table 5. Chemical, Mechanical and Electrical Properties of Composites Based on APEAs-MMA Blends.

\begin{tabular}{|c|c|c|c|c|c|c|}
\hline \multirow{2}{*}{ Composites } & \multicolumn{2}{|c|}{$\begin{array}{l}\text { \% Change on exposure to } 25 \% \\
(\mathrm{~W} / \mathrm{V}) \mathrm{NaOH}\end{array}$} & \multirow{2}{*}{$\begin{array}{c}\text { Compressive } \\
\text { strength (MPa) }\end{array}$} & \multirow{2}{*}{$\begin{array}{c}\text { Impact } \\
\text { Strength (MPa) }\end{array}$} & \multirow{2}{*}{$\begin{array}{c}\text { Rockwell } \\
\text { hardness (R) }\end{array}$} & \multirow{2}{*}{$\begin{array}{c}\text { Electrical } \\
\text { strength } \\
\text { (in air) } \\
(\mathrm{kV} / \mathrm{mm})\end{array}$} \\
\hline & Thickness & Weight & & & & \\
\hline $5 a$ & 0.78 & 1.07 & 460 & 424 & 111 & 22.65 \\
\hline $5 b$ & 0.81 & 1.10 & 467 & 456 & 104 & 19.45 \\
\hline $5 c$ & 0.79 & 1.02 & 478 & 447 & 106 & 23.35 \\
\hline
\end{tabular}




\section{ASTM 0638.}

All mechanical and electrical tests were performed using three specimens and their average results are summarized in Table 5.

\section{Results and Discussion}

The unsaturated bisamic acids were prepared by the reaction of malelic anhydride (2.0 mole) and aliphatic diamines (1.0 mole) by following method reported in literature $[7,8]$. Unsaturated poly(ester-amide)s (PEAs) was prepared by reaction of epoxy resin (DGEBA) with unsaturated bisamic acids using triethylamine (TEA) as a base catalyst. The post reactions of all these unsaturated poly(ester-amide)s (PEAs) were carried out with acryloyl chloride. The resultant products are called acrylated poly (ester-amide)s (APEAs). Blending of acrylated poly(ester-amide)s APEAs with vinyl ester (VE) resin was also carried out. The resultant products are called APEAs-VE blends.

The $\mathrm{C}, \mathrm{H}, \mathrm{N}$ content of all the unsaturated poly(esteramide)s (PEAs) and acrylated poly (ester-amide)s (APEAs) were estimated by means of Thermofinagan 1101 Flash Elemental Analyzer (Italy). The values of C, $\mathrm{H}, \mathrm{N}$ of each of the unsaturated poly(ester-amide)s (PEAs) and acrylated poly (ester-amide)s (APEAs) were consistent with their predicted structures and are furnished in Tables 1 and 2. The number average molecular weight of both unsaturated poly (ester-amide)s (PEAs) and acrylated poly (ester-amide)s (APEAs) were estimated by non-aqueous conductometric titration method [14]. Their results are furnished in Tables $\mathbf{1}$ and 2, respectively. The results indicate that the degree of polymerization of both unsaturated poly (ester-amide)s (PEAs) and acrylated poly (ester-amide)s (APEAs) is about 6. The IR spectra were consistent with the ones expected from the structures of the PEAs (3a-c) and APEAs (4a-c).

Numbers of hydroxyl group present per repeating unit in unsaturated poly(ester-amide)s (PEAs) was also analyzed by employing acetylating method [15]. Also, acrylated poly(ester-amide)s (APEAs) were characterized for the presence of double bonds per repeating unit employing mercury-catalyzed bromate-bromide method [16]. Satisfactory results were found and the results are furnished in Tables 1 and 2 respectively.

Curing of all these APEAs-VE blends were carried out on a differential scanning calorimeter (DSC) by using benzoyl peroxide as a catalyst. The data of DSC thermograms of all APEAs-VE are furnished in Table 3.

The unreinforced cured samples of APEAs-VE blends were also analyzed by thermo gravimetric analysis (TGA). The result reveals that the cured sample starts their degradation at about $150^{\circ} \mathrm{C}$ and their initial weight is about $2 \%-3 \%$. This small weight loss may be due to either in sufficient curing of components used or due to the catalyst used. A weight loss of about $10 \%-11 \%$ is found at $300^{\circ} \mathrm{C}$. However, the rate of decomposition increases very rapidly between $300^{\circ} \mathrm{C}$ to $450^{\circ} \mathrm{C}$ and the products are lost completely beyond $750^{\circ} \mathrm{C}$. TGA data of all the samples are shown in Table 4.

The glass and carbon fiber reinforced composites of all APEAs-VE blends were prepared based on their DSC data. The composites were characterized for their chemical, mechanical and electrical properties. Their results are furnished in Table 5. The results shows that composites have good chemical resistant property, good mechanical and electrical strength.

\section{REFERENCES}

[1] V. Shukla, "Flow Modified Epoxy Resin: The Complete Solution of Aerosol in 2-Pack Epoxy Adhesive," Pigment \& Resin Technology, Vol. 35, No. 6, 2006, pp. 353-357. doi:10.1108/03699420610711362

[2] B. C. Samanta, T. Maity, S. Dalai and A. K. Banthia, "Influences of Amine-Terminated Oligomers on Glass Fibre-Epoxy Composite," Pigment \& Resin Technology, Vol. 37, No. 1, 2008, pp. 3-8. doi: $10.1108 / 03699420810839648$

[3] S. Khambete, "U. S. Patent," Vol. 7, November 2007, pp. 290-300.

[4] M. Malik, V. Choudhary and I. K. Varma, "Current Statuse of Unsaturated Polyester Resin," Journal of Macromolecular Science-Reviews in Macromolecular Chemistry \& Physics, Vol. 40, No. 2, 2000, pp. 139-165.

[5] A. J. Pekarik, "U. S. Patent," Vol. 4, June 1989, pp 840,980 .

[6] S. Ahmad, S. M. Ashraf, A. Hasant, S. Yadav and A. Jamal, "Studies on Urethane-Modified Alumina-Filled Polyesteramide Anticorrosive Coatings Cured at Ambient Temperature," Journal of Applied Polymer Science, Vol. 82, No. 8, 21 November 2001, pp. 1855-1865.

[7] H. S. Patel and K. K. Panchal, "Novel Unsaturated Polyester Resins Containing Epoxy Residues," International Journal of Polymeric Materials, Vol. 54, No. 1, 2005, pp. 1-7. doi:10.1080/00914030390224247

[8] H. S. Patel and K. K. Panchal, "Flame Retardant Unsaturated Poly(Ester Amide) Resins Based on Epoxy Resins," International Journal of Polymeric Materials, Vol. 54, No. 9, 2005, pp. 795-803. doi: $10.1080 / 00914030490463133$

[9] H. S. Patel and B. K. Patel, "Novel Flame-Retardant Acrylated Poly(Ester-Amide) Resins Based on Brominated Epoxy," International Journal of Polymeric Materials, Vol. 56, No. 6, 2009, pp. 312-321. doi:10.1080/00914030902859257

[10] H. S. Patel, and B. K. Patel, "Interacting Blends of Novel Acrylated Poly(Ester Amide)s Based on DGEBC with Styrene Monomer," International Journal of Polymeric Materials, Vol. 58, No. 12, 2009, pp. 654-664. doi:10.1080/00914030903146720 
[11] A. M. Atta, S. M. ElSaeed and R. M. Farag, "New Vinyl Ester Resins Based on Rosin for Coating Applications," Reactive and Functional Polymer, Vol. 66 No. 12, December 2006, pp. 1596-1608.

[12] I. K. Varma, "Matrix Resin for Composite," Department of Science and Technology Government of India, 1986, p. 148.

[13] R. S. Darke, D. R. Egan and W. T. Murphy, "Elastomer-Modified Epoxy Resins in Coatings Applications," ACS Symposium Series, Vol. 221, 1982, pp. 1-20. doi:10.1021/bk-1983-0221.ch001
[14] R. N. Patel and S. R. Patel, "Synthesis and Characterization of Poly(Keto-Amines). 1. Self Polycondensation of 4-Aminophenacyl Chloride," Die Angewandte Makromolekulare Chemie, Vol. 96 No. 1, May 1981, pp. 85-92. doi:10.1002/apmc.1981.050960107

[15] A. I. Vogel, "Quantitative Organic Analysis," CBS Publishers, New Delhi, Vol. 3, No. 2, 1998, pp. 677-679.

[16] A. I. Vogel, "Quantitative Organic Analysis," CBS Publishers, New Delhi, Vol. 3 No. 2, 1998, pp. 765-766. 